DOI: $10.19195 / 2300-7729.35 .6$

\title{
Uczelniana baza wiedzy jako przykład systemu CRIS. Z doświadczeń Biblioteki Głównej Politechniki Warszawskiej
}

\section{Wstęp}

Biblioteki akademickie od pewnego czasu stoją w obliczu nieuchronnych zmian, które muszą przeprowadzić, chcąc zachować przydatność dla uczelni i przetrwać $\mathrm{w}$ zmieniającym się środowisku. Wiele zjawisk związanych z rozwojem nowych technologii, pozwalających na łatwy dostęp do informacji on-line, takich jak: spadająca liczba wypożyczeń, ograniczenie roli wypożyczeń międzybibliotecznych, zmniejszająca się liczba kupowanych nowych tytułów, stale rosnący koszt licencjonowanych informatycznych systemów bibliotecznych, rozwój centralnych katalogów, krajowych i światowych, dostępne w Internecie zasoby wiedzy (bazy, podręczniki, e-learning) sprawiają, że tradycyjna działalność bibliotek coraz bardziej ulega ograniczeniom ${ }^{1}$.

Biblioteki akademickie muszą znaleźć swoje miejsce w zmienionym środowisku. Poza zapewnieniem społeczności akademickiej przyjaznej przestrzeni do nauki - indywidualnej i grupowej, dostarczaniem informacji wspomagających proces kształcenia oraz badania naukowe $\mathrm{w}$ formie tradycyjnej czy zaawansowanej technologicznie biblioteki powinny przygotować się do wypełniania nowych zadań na rzecz uczelni, wspierania wewnętrznych działań placówki w ściślejszej współpracy z władzami uczelni i pracownikami naukowymi.

Szkoły wyższe w coraz większym zakresie obligowane są do sprawozdawczości i nowych wymogów parametryzacji jednostek naukowych. Bibliotekarze

${ }^{1}$ J. Stępniak, Krajowy system informacji o nauce - szansą dla bibliotek szkót wyższych. VII Konferencja Biblioteki Politechniki Łódzkiej „Rozmowy o bibliotekach”, 22-24 czerwca 2016 r. Łódź-Rogów, http://7kbpl.systemcoffee.pl/userfiles/file/prezentacje/11-Stepniak.pdf [dostęp: 7.07.2016]. 
mogą wspomagać obsługę zarówno lokalnych systemów informacyjnych ewidencjonujących dorobek naukowo-badawczy uczelni, jak i proces zasilania stale rozbudowującego się Krajowego Systemu Informacji o Nauce. Dostarczanie danych do centralnego systemu informacji wymaga ewidencjonowania i dokumentowania działalności uczelni w szerokim zakresie. Dane te obrazują realne osiągnięcia naukowe (realizowane projekty, uzyskane patenty, zorganizowane konferencje, przyznane nagrody, opublikowane prace) i potencjalne możliwości (infrastruktura, laboratoria badawcze i aparatura, biblioteki, inwestycje, wydawane czasopisma). Informacje te często są już w jakiejś mierze rejestrowane w prowadzonych w bibliotekach systemach ewidencji dorobku naukowego, w katalogach patentów, projektów, prac dyplomowych i rozpraw doktorskich.

Jednym z zadań bibliotek naukowych od dawna było dokumentowanie dorobku naukowego pracowników uczelni, w postaci różnego rodzaju bibliografii oraz baz bibliograficznych. Zadanie to, rozumiane znacznie szerzej, może objąć rejestrowanie różnych aspektów działalności uczelni, w tym współtworzenie uczelnianej bazy wiedzy, a także innych form gromadzenia i udostępniania informacji.

W administracji uczelni nie ma jednostek organizacyjnych i osób wyspecjalizowanych w pracy w centralnych systemach informacji, a biblioteki dysponują specjalistami od gromadzenia i opracowania informacji (dokumentowania publikacji, danych faktograficznych). Pracownicy wykonujący tego typu zadania są znaczną grupą zatrudnionych w bibliotekach. Stwarza to szansę na nową ścieżkę działań biblioteki uczelnianej, ściśle związaną z akademickim środowiskiem badawczym.

\section{Systemy CRIS a repozytoria instytucjonalne}

Środowisko naukowe zmierza w kierunku nadania zasięgu międzynarodowego gromadzeniu i udostępnianiu informacji o naukowcach, prowadzonych projektach badawczych, instytucjach, publikacjach, wynikach badań, ich finansowaniu.

Dwa główne komponenty sfery zarządzania informacją o badaniach naukowych to repozytoria instytucjonalne i systemy CRIS (Current Research Information System) $)^{2}$. Rosnące znaczenie strategiczne tych systemów i repozytoriów dla instytucji szkolnictwa wyższego i badań naukowych wynika z potrzeby wspierania badań i innowacji.

Repozytorium instytucjonalne, często oznaczone „IR”, można zdefiniować jako zbiór wyników badań (głównie publikacji i baz danych) tworzony w celu

${ }^{2}$ P. De Castro, 7 things you should know about..., Institutional Repositories, CRIS Systems, and their Interoperability, https:/www.coar-repositories.org/activities/repository-observatory/thirdedition-ir-and-cris/7-things-you-should-know-about-institutional-repositories-cris-systems-andtheir-interoperability/ [dostęp: 8.07.2016]. 
gromadzenia, zachowania i upowszechniania dorobku intelektualnego uczelni $\mathrm{i}$ instytucji naukowo-badawczych.

Zarówno rola CRIS, jak i repozytoriów wzrosła znacząco w ciągu ostatnich kilku lat. Systemy stopniowo zyskują kolejne funkcje i narzędzia, a ich funkcja $\mathrm{w}$ instytucjach stale się zmienia, zgodnie z nowymi zasadami: polityki otwartego dostępu, kryteriów oceny parametrycznej jednostek naukowych i sposobów finansowania. W wyniku tych procesów można zaobserwować systemy CRIS działające jako repozytoria i repozytoria o rozszerzonych modelach danych na wzór CRIS, a także bazy określające się jako i repozytorium, i system CRIS. Widoczny jest szeroki zakres interoperacyjności pomiędzy współistniejącymi systemami CRIS i repozytoriami.

Wzorcowym systemem baz danych, przechowującym informacje o prowadzonych projektach badawczych, instytucjach i osobach związanych z badaniami oraz o programach finansowania badań w Europie jest Euro CRIS - Current Research Information System ${ }^{3}$ (http://www.eurocris.org/), pełniący funkcję centrum informacji o środowisku badawczym dla różnych zastosowań w zakresie zarządzania badaniami naukowym w Europie.

Systemy baz danych typu CRIS wdrażane są zarówno na szczeblu centralnym — krajowym (np. norweski CRIStin), jak i lokalnym, gromadząc informacje służące prezentowaniu dorobku naukowego, współpracy z innymi instytucjami naukowymi i przemysłem, a także ewaluacji i przekazywaniu danych do centralnych systemów informacji o nauce.

\subsection{Różnice między systemami CRIS a instytucjonalnymi repozytoriami}

Zarówno systemy CRIS, jak i repozytoria instytucjonalne są platformami służącymi do zarządzania informacjami pozyskiwanymi z prowadzonych w środowisku naukowym badań. Celem obu systemów jest zbieranie informacji na podstawie danych dostarczonych przez badaczy i administratorów badań, bezpośrednio lub za pośrednictwem takich instytucji, jak biblioteki, urzędy badawcze, biura ds. nauki, wydawnictwa i bazy danych.

Oprócz tych podstawowych podobieństw istnieją też istotne różnice w funkcjonalności i podejściu CRIS oraz repozytoriów instytucjonalnych do kierunku i metod gromadzenia, rozpowszechniania i zarządzania informacjami badawczymi.

Systemy CRIS skupiają się na objęciu całości instytucjonalnej działalności badawczej, w tym projektów badawczych, grantów, osób, organizacji, produktów

${ }^{3}$ L. Ribeiro, P. De Castro, M. Mennielli, EUNIS - euroCris joint Survey on CRIS and IR. Final Report, s. 7, http://www.eunis.org/wp-content/uploads/2016/03/cris-report-ED.pdf [dostęp: 8.07.2016]. 
i urządzeń badawczych. Repozytoria kładą nacisk na gromadzenie instytucjonalnych wyników prac naukowych, rozszerzając stopniowo zakres poza publikacje instytucjonalne, które są głównym elementem repozytoryjnych zasobów.

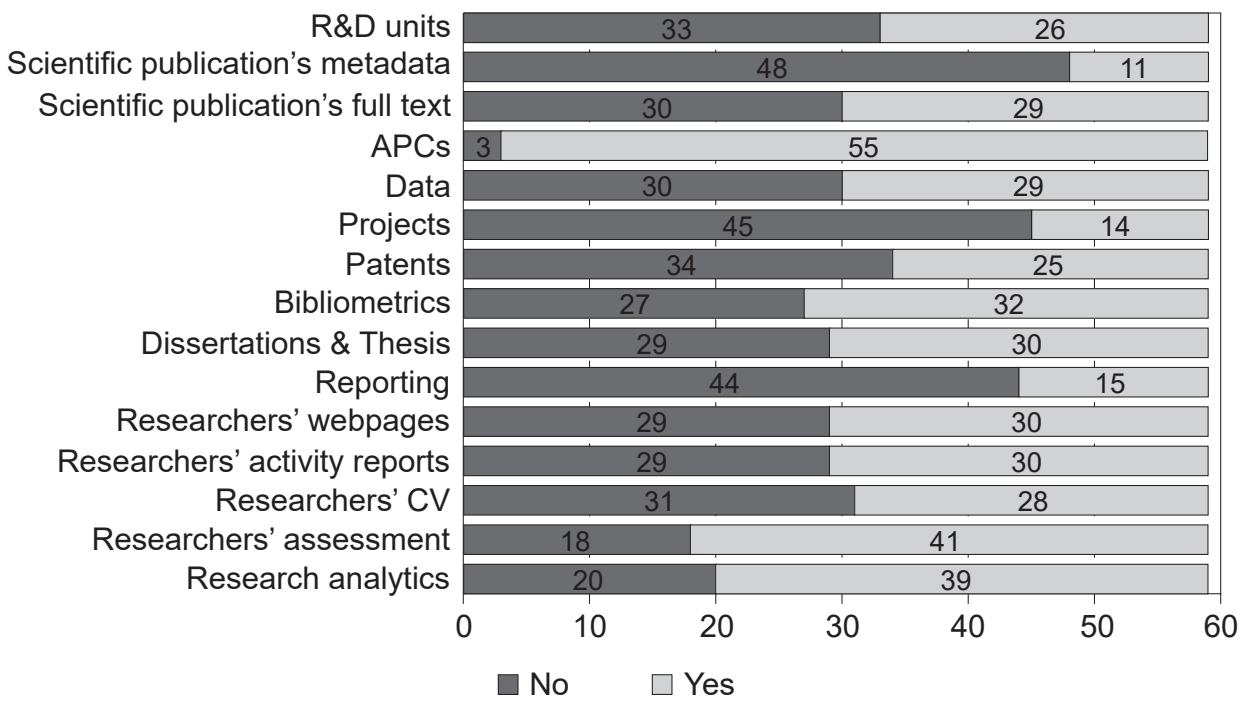

Rys. 1. Główne funkcjonalności CRIS

Źródło: EUNIS - euroCris joint Survey on CRIS and IR. Final Report, marzec $2016^{4}$.

Różnice występują też w takich aspektach, jak cele, do jakich wykorzystywane są informacje, w obszarze organizacyjnym, metodologii gromadzenia i kryteriach udostępniania danych.

CRIS zbiera szeroko rozumiane informacje badawcze w celu opisania instytucjonalnej działalności badawczej na potrzeby raportowania, zarówno na poziomie instytucji, jak i na szczeblu rządowym. Głównym zadaniem repozytoriów jest gromadzenie i upowszechnianie wyników badań instytucjonalnych, ze szczególnym naciskiem na publikacje. Repozytoria były uruchamiane i rozwijane w dużej mierze dzięki międzynarodowemu ruchowi otwartego dostępu, którego celem jest zapewnienie bezpłatnego dostępu do finansowanych ze środków publicznych instytucjonalnych publikacji naukowych i zwalczanie barier, które ten dostęp ograniczają.

Systemy CRIS i repozytoria tradycyjnie zarządzane były przez inne jednostki instytucjonalne. Pierwotne założenie było takie, że CRIS związany jest z urzędami badawczymi, zarządzającymi projektami badawczymi, a repozytoria powinny być prowadzone i utrzymywane przez instytucje, które zwykle zajmują się gromadzeniem i udostępnianiem publikacji, czyli biblioteki. Instytucje te mają

\footnotetext{
${ }^{4}$ Ibidem, s. 12.
} 
za sobą długą drogę w rozwijaniu współpracy między sobą, ale nadal istnieje pewna asymetria $\mathrm{w}$ zarządzaniu informacją. Biblioteki tradycyjnie poczuwają się do rozpowszechniania wśród naukowców idei open access oraz prowadzenia repozytoriów instytucjonalnych.

Systemy CRIS, wykorzystujące dokładne dane do raportowania, skupione są na metadanych jednoznacznych, kompletnych, spójnych i aktualnych. Repozytoria również stosują metadane do opisu obiektów cyfrowych, lecz kładą nacisk na przechowywanie i udostępnianie pełnej zawartości plików z treścią, a także na metody archiwizacji, zachowania i ponownego użycia obiektów cyfrowych. Wiele z nich korzysta jednak z większej liczby elementów metadanych niż tylko tych potrzebnych do opisu pełnego tekstu. $Z$ technicznego punktu widzenia główna różnica między CRIS a instytucjonalnymi repozytoriami polega właśnie na standardach metadanych, których używają, przy czym jest ona zapewne zasadniczą barierą ich interoperacyjności.

Najbardziej rozpowszechnionym standardem metadanych CRIS jest Common European Research Information Format (CERIF) ${ }^{5}$. Jego obecna implementacja znacząco różni się w poszczególnych krajach, jednak szybko staje się standardem domyślnym, który może zapewnić interoperacyjność na wyższym poziomie, wymianę danych nie tylko z repozytoriami, ale też z fundatorem czy centralnymi systemami oceny badań. Podstawowym standardem metadanych używanym w repozytoriach jest Dublin Core lub QDC (Qualified Dublin Core) wraz z zestawem dodatkowych, nieco bardziej skomplikowanych modeli, takich jak METS (Metadata Encoding and Transsmission Standard) lub PREMIS (Preservation Metadata: Implementation Strategies) ${ }^{6}$. Standardy metadanych stosowane w repozytoriach często uważane są za niewystarczająco elastyczne do opisywania złożonych obszarów semantycznych, takich jak finansowanie badań, jednakże niezwykła szybkość implementacji repozytoriów wynika po części właśnie z prostoty stosowanego modelu metadanych.

Oba standardy metadanych CRIS i IR ewoluują w kierunku bardziej złożonych modeli danych, które pozwolą na głębszą współpracę między nimi.

Oprogramowanie wykorzystywane w bazach typu CRIS to zazwyczaj systemy komercyjne, chociaż niektóre instytucje decydują się na zastosowanie oprogramowania własnego, dostosowanego do specyficznych potrzeb w zakresie sprawozdawczości. Repozytoria instytucjonalne oparte są zwykle na platformach Open Source.

W związku ze sposobem podejścia do dzielenia się danymi, ich udostępniania - repozytoria są z założenia otwarte, systemy CRIS dopiero od niedawna systematycznie ujawniające szerzej, poza własne środowisko, informacje — społeczności obu systemów różnią się. Obecnie, zgodnie z potrzebami środowiska naukowego, dzięki stosowaniu narzędzi zwiększających interoperacyjność obu systemów i ich funkcjonalność, większość tych różnic szybko zanika.

${ }^{5}$ Open AIRE Guidelines for CRIS Managers based on CERIF-XML, https://guidelines.openaire.eu/wiki/OpenAIRE_Guidelines:_For_CRIS [dostęp: 8.07.2016].

${ }^{6}$ PREMIS Data Dictionary for Preservation Metadata, Version 3.0, http://www.loc.gov/ standards/premis/v3/premis-3-0-final.pdf [dostęp: 8.07.2016]. 
Główne różnice między repozytoriami instytucjonalnymi a systemami CRIS to:

Tabela 1. Analiza porównawcza IR i CRIS

\begin{tabular}{|c|c|}
\hline Repozytoria instytucjonalne & System CRIS \\
\hline Biblioteka & Biuro ds. badań \\
\hline Wyniki badań (głównie publikacje) & Całość działań wokół badań \\
\hline Udostępnianie & Raportowanie \\
\hline Pełne teksty & Metadane \\
\hline Dublin Core & CERIF \\
\hline Otwarte dane (darmowe) & Zamknięte (komercyjne) \\
\hline
\end{tabular}

Źródło: P. De Castro, op. cit.

Wyszczególnione różnice opisane zostały właściwie w ujęciu „historycznym” i występują bardziej w teorii niż w praktyce, gdyż oba systemy ewoluują w kierunku stopniowej integracji.

\subsection{CRIS, repozytorium czy dwa w jednym}

Systemy CRIS i repozytoria nie są kompatybilne, stanowiąc dotychczas rozwiązania dla różnych potrzeb instytucjonalnych i zazwyczaj działając jako oddzielne instalacje. Jednakże poprawa funkcjonalności systemu CRIS, dodanie narzędzi i funkcji, tradycyjnie dostarczanych przez repozytoria, takich jak protokół OAI-PMH, udostępnianie plików z treścią publikacji, sprawia, że część instytucji postrzega CRIS jako wystarczająco zaawansowany system do zastąpienia repozytorium instytucjonalnego. System, który może spełniać wszystkie zadania związane $\mathrm{z}$ zarządzaniem badaniami, włączając $\mathrm{w}$ to dokumentację projektów badawczych i proces raportowania na potrzeby oceny działalności badawczej. Rosnący stopień zachodzenia na siebie funkcjonalności obu systemów przy ściśle monitorowanych kosztach utrzymywania dwóch instalacji jest jednym z powodów zastępowania repozytorium instytucjonalnego przez CRIS. Takie sytuacje występują zazwyczaj w instytucjach badawczych, gdzie współistnieją oba systemy. Mniejsze instytucje opierają się na wykorzystywaniu do zarządzania informacjami badawczymi własnego repozytorium, nie decydując się na wdrażanie systemu CRIS.

Repozytorium może (do pewnego stopnia) odgrywać rolę CRIS przez rozszerzenie podstawowego modelu danych w celu zbierania dodatkowych informacji badawczych poza wynikami badań (w ograniczeniu: publikacjami). Standard Dublin Core może być swobodnie poszerzony o dodatkowe atrybuty w celu opisu dodatkowych obszarów badawczych, takich jak np. projekty badawcze. Tego typu rozwiązanie zostało wdrożone np. kilka lat temu przez zespół platformy EPrints w Southampton?

\section{${ }^{7}$ Ibidem.}


Istnieje kilka przykładów dobrych praktyk dla repozytoriów spełniających funkcję CRIS. Jeden z najbardziej zaawansowanych to prawdopodobnie Research Hub w Hong Kong University (HKU $)^{8}$, gdzie oprogramowanie DSpace wykorzystywane w repozytoriach przekształciło się w DSpace-CRIS. Inny przykład to repozytorium „Enlighten” Uniwersytetu w Glasgow ${ }^{9}$, gdzie w 2010 r. uruchomiono wymianę metadanych między systemem CRIS a repozytorium „Enlighten”, co pozwoliło do metadanych bibliograficznych opisujących publikacje w repozytorium dołączyć dane o ich finansowaniu. Metadane do systemu zarządzania informacjami badawczymi i do repozytorium Uniwersytetu w Glasgow są pobierane też automatycznie ze światowych baz Web of Science i Scopus, przy czym do importowania danych do repozytorium „Enlighten” ${ }^{10}$ wykorzystywane są numery DOI. Zaimportowane rekordy są następnie weryfikowane przez bibliotekarzy i podłączane do publikacji autorów UG przed ich otwartym udostępnieniem.

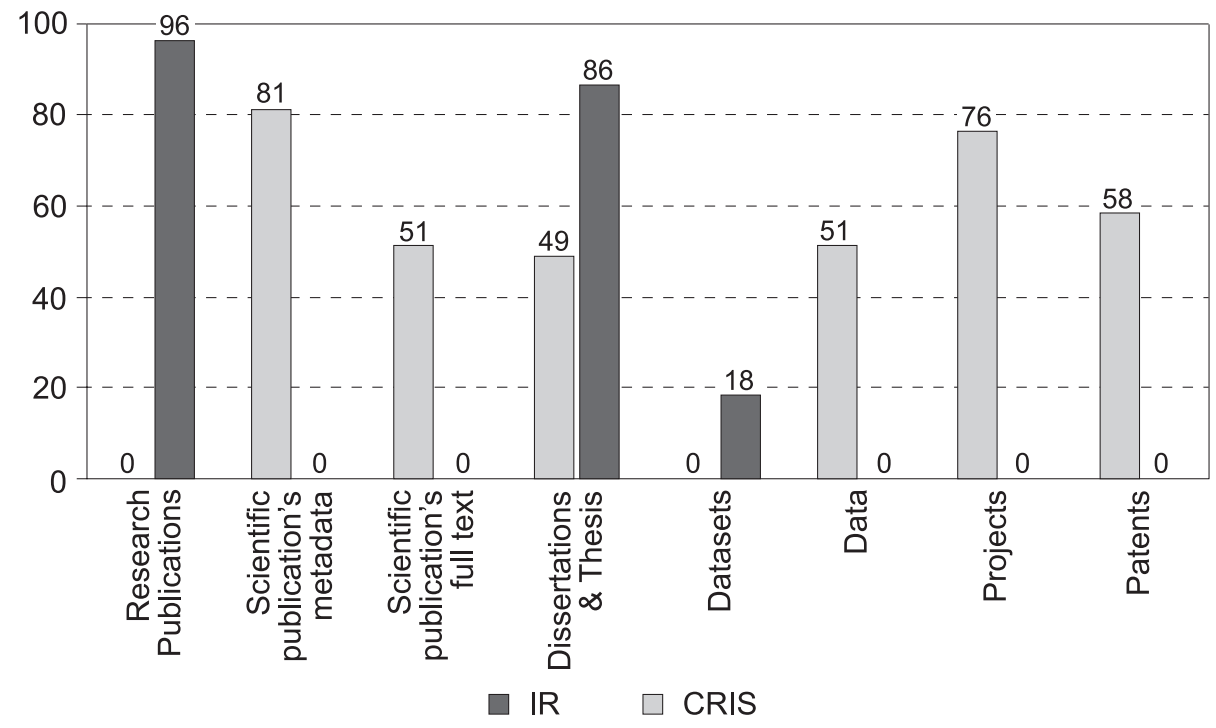

Rys. 2. Typy danych przechowywane w systemach CRIS i repozytoriach Źródło: L. Ribeiro, P. De Castro, M. Mennielli, op. cit., s. 17.

Nie wydaje się jednak, że repozytoria będą z założenia przekształcać się w komercyjne systemy CRIS, gdyż szerokie zarządzanie informacją badawczą nie jest ich głównym celem. Będą jednak w stanie dostarczyć wystarczającą funkcjonalność dla potrzeb instytucji nieplanującej uruchomienia zaawansowanego

${ }^{8}$ Ibidem.

${ }^{9}$ W.J. Nixon, Enrich: Improving integration between an Institutional Repository and a CRIS at the University of Glasgow, http://www.eurocris.org/Uploads/Web\%20pages/cris2010_ papers/Papers/cris2010_Nixon.pdf [dostęp: 12.07.2016].

${ }^{10}$ University of Glasgow: Enlighten IR and Research System, https://www.coar-repositories. org/files/Profile-UofG.pdf [dostęp: 9.07.2016]. 
systemu CRIS. Wskazują na to inicjatywy zakładające rozbudowywanie metadanych repozytorium, takie jak np. RIOXX (RIOXX Metadata Application Profile) ${ }^{11}$ w Wielkiej Brytanii czy rozszerzenie wytycznych OpenAIRE na poziomie europejskim wspierające ideę wzmocnienia instytucjonalnych repozytoriów poprzez zapewnienie środków technicznych, umożliwiających zbieranie i przekazywanie informacji o projektach badawczych w sposób interoperacyjny.

Jaki model konfiguracji wybierze instytucja badawcza - utrzymywanie obu systemów, zwiększenie funkcjonalności systemu CRIS czy rozbudowę repozytorium - zależy od wielu czynników, takich jak wielkość instytucji, jej potrzeby raportowania, gromadzone zasoby, a także znaczenie i pozycja różnych jednostek instytucjonalnych w określonym momencie.

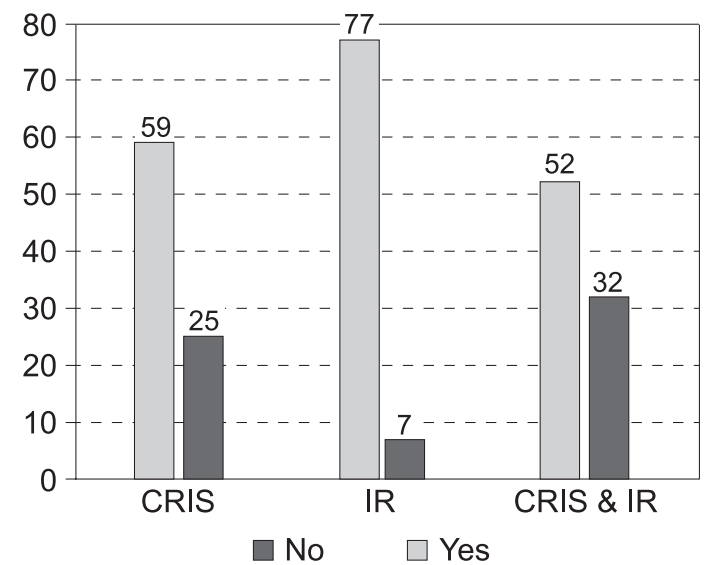

Rys. 3. Stosowane konfiguracje: CRIS, repozytoria instytucjonalne oraz CRIS i IR

Źródło: L. Ribeiro, P. De Castro, M. Mennielli, op. cit., s. 10.

\section{Baza Wiedzy Politechniki Warszawskiej jako przykład systemu CRIS i instytucjonalnego repozytorium}

Działająca od 2013 r. Baza Wiedzy Politechniki Warszawskiej została powołana Uchwałą Senatu PW w 2012 r. ${ }^{12}$ Uchwała wprowadziła obowiązek wyłącznego stosowania od 2014 r. danych z systemu do przygotowywania sprawozdań, przed-

11 P. De Castro, op. cit.

12 Uchwała nr 26/XLVIII/2012 Senatu Politechniki Warszawskiej z dnia 21 listopada 2012 r. w sprawie utworzenia centralnego systemu ewidencji i archiwizacji dorobku piśmienniczego, wydawniczego i dydaktycznego, pracowników, doktorantów, studentów i jednostek Uczelni oraz re- 
kładania pisemnej informacji o jednostce uczelni oraz o osobach, których dorobek naukowy, dydaktyczny i techniczny podlega ocenie w zakresie objętym systemem ewidencji dorobku naukowego PW. Uchwała zobowiązuje pracowników PW do rejestracji i archiwizacji publikacji powstałych po 1 stycznia $2013 \mathrm{r}$.

Zasady tworzenia systemu ewidencji i archiwizacji dorobku naukowego oraz repozytorium ujęte zostały w Zarządzeniu nr 3/2014 Rektora Politechniki Warszawskiej z dnia 29 stycznia 2014 r. $^{13}$

Koncepcja, projekt techniczny oraz implementacja oprogramowania Bazy Wiedzy PW (Omega-PSIR) ${ }^{14}$ opracowane zostały na Wydziale Elektroniki i Technik Informacyjnych PW w Instytucie Informatyki w ramach projektu SYNAT. Za organizację prac związanych z wdrożeniem projektu, przygotowanie podstaw prawnych wdrożenia, prowadzenie szkoleń oraz weryfikację danych odpowiada Biblioteka Główna PW.

Integralną częścią Bazy Wiedzy od początku było repozytorium uczelniane. Jednakże zakładano od razu, że system nie może ograniczać się tylko do funkcji repozytorium. Uczelniana Baza Wiedzy powinna obejmować szeroki zakres danych dotyczących różnych aspektów działalności badawczej i stanowić centralne źródło informacji na temat naukowców i ich działalności. Wszystkie te typy danych powinny być połączone ze sobą, umożliwiając budowę bazy semantycznej. Założono, że oprogramowanie musi być wystarczająco elastyczne, żeby zapewnić łatwość wdrożenia nowych typów obiektów i nowych relacji. Przyjęto też, że dostarczone narzędzia administracji systemem powinny cechować się elastycznością, umożliwiającą definiowanie nowych struktur danych ${ }^{15}$.

W miarę rozwoju Bazy rozszerzano typy gromadzonych danych. Poza metadanymi opisującymi publikacje (książki, artykuły, rozdziały, tłumaczenia, prace doktorskie, licencjackie, magisterskie, raporty) Baza zbiera informacje o patentach, projektach, produktach, technologiach, aktywności zawodowej naukowców, osiągnięciach zawodowych (karierze), wdrożeniach i efektach praktycznych (patentów, produktów), dziełach architektonicznych lub wzorniczych, czasopismach wydawanych przez jednostkę, organizowanych konferencjach. Moduł „technologie", zawierający listę technologii przeznaczonych do komercjalizacji, prowadzony jest przez Instytut Badań Stosowanych Politechniki Warszawskiej. Baza

pozytorium Politechniki Warszawskiej, https://www.bip.pw.edu.pl/content/download/23324/218057/ file/26.pdf [dostęp: 7.07.2016].

13 Zarządzenie nr 03/2014 Rektora Politechniki Warszawskiej z dnia 29 stycznia 2014 r. w sprawie centralnego systemu ewidencji i archiwizacji dorobku piśmienniczego, wydawniczego i dydaktycznego, pracowników, doktorantów, studentów i jednostek Uczelni oraz Repozytorium Politechniki Warszawskiej, https://bip.pw.edu.pl/content/download/25491/241495/file/z\%20 3_2014.pdf [dostęp: 7.07.2016].

${ }^{14}$ H. Rybiński et al., OMEGA-PSIR: From the Repository to the Research Knowledge Base of Warsaw University of Technology, „Foundations of Management” 2013 (5), nr 1, s. 53-68.

15 Ł. Skonieczny, OMEGA-PSIR. Nowe funkcje. Październik 2015-Czerwiec 2016, http:// repo.bg.pw.edu.pl/images/dokumenty/omega_news_skonieczny-1.pdf [dostęp: 13.07.2016]. 
Wiedzy PW napełniana jest danymi z wielu źródeł. Podstawą są informacje wprowadzane przez sieć redaktorów jednostek (bibliotekarze wydziałowi, pracownicy sekretariatów, a także młodsi pracownicy naukowi).

Wprowadzanie danych zostało częściowo zautomatyzowane, dane mogą być importowane za pomocą programu Zotero z baz i portali naukowych, konwertowane $\mathrm{z}$ lokalnych baz wydziałowych oraz wprowadzane przez samych naukowców w formacie BibTex.

Autoryzowany użytkownik (autor) ma możliwość samodzielnej edycji własnego profilu w Bazie Wiedzy PW. Może modyfikować informacje takie, jak dane formalno-adresowe, opis działalności naukowej; może też dodać zdjęcie, zaimportować wykaz własnych publikacji i dołączyć plik z treścią publikacji.

BWPW zapewnia integrację z Google Scholar i Web of Science. Podawane są liczne wskaźniki typu Indeks Hirscha, Impact Factor, cytowania według Google Scholar oraz WoS. Zapewniono ponadto możliwość komunikacji z mediami społecznościowymi (m.in. Research Gate, Facebook, Twitter, Linkedln) ${ }^{16}$.

Jedną z ważniejszych funkcji jest możliwość raportowania, zarówno na potrzeby naukowców, władz uczelni, jak i systemów zewnętrznych, np. ministerialnych. Funkcja ta jest także wykorzystywana do przesyłania danych do Polskiej Bibliografii Naukowej - modułu sprawozdawczego ${ }^{17}$. Baza Wiedzy PW gromadzi dane, które są przekazywane do systemów zewnętrznych typu POL-on czy PBN-MS zgodnie z Rozporządzeniem Ministerstwa Nauki i Szkolnictwa Wyższego z dnia 29 czerwca 2015 r. w sprawie Systemu Informacji o Nauce ${ }^{18}$.

Cechą unikalną oprogramowania Omega-PSIR jest zastosowanie automatycznego naliczania punktów na podstawie opisu publikacji przy zastosowaniu modyfikowalnych reguł punktujących.

Jednym z zasadniczych zadań Bazy jest objęcie całego procesu badawczego, zawierającego:

— pomysły, plany badawcze;

— wniosek projektowy;

- projekt;

— publikacje, patenty;

— wdrożenia.

Funkcjonalność Bazy Wiedzy z założenia zorientowana jest na naukowca, którego profil powinien prezentować różne aspekty aktywności badacza i inte-

16 Ibidem.

${ }^{17}$ M. Lewandowska-Tranda, W. Struk, Omega PSIR a krajowy System Informacji o Nauce. Z doświadczeń Politechniki Warszawskiej, http://www.bg.pw.edu.pl/dane/publikacje/20_10_2015 Sem_Omega_PSIR_WS_v2.pdf [dostęp: 11.07.2016].

${ }^{18}$ Rozporządzenie Ministerstwa Nauki i Szkolnictwa Wyższego z dnia 29 czerwca 2015 r. w sprawie Systemu Informacji o Nauce, Dz.U. 2015, poz. 944, http://isap.sejm.gov.pl/DetailsServlet?id=WDU20150000944 [dostęp: 8.07.2016]. 
grować pełną wiedzę o nim w jednym miejscu. Baza Wiedzy umożliwia generowanie szeregu rodzajów raportów zarówno dla autora (raport dorobku, statystyki, współpraca, aktywność, osiągnięcia, cytowania), jak i dla jednostki uczelnianej.

W profilu jednostki system daje możliwość generowania dorobku jednostki (sprawozdanie z działalności, analizę bibliometryczną, publikacje w czasopismach), a także statystyki, współpracę pracowników, współpracę wewnętrzną i zewnętrzną.

\section{Profil Statystyki Wspótpraca pracowników Wspó́praca}

Wydział Chemiczny
Politechnika Warszawska
Strona domowa

Rys. 4. Profil jednostki naukowej (wydziału) Źródło: zrzut ekranu z Bazy Wiedzy PW.

Poza pracownikami naukowymi i dydaktycznymi uczelni, wśród głównych beneficjentów BW PW należy wymienić: jednostki uczelni — wydziały, instytuty, zakłady; kierownictwo uczelni: rektorat, dziekanaty, administrację (sekretariaty, biura projektów), studentów, bibliotekarzy.

Cechą charakterystyczną systemu Omega-PSIR jest to, że raz wprowadzone dane mogą być wykorzystywane do różnych celów przez różne jednostki naukowe, instytucje czy grupy korzystających.

Z systemu informacji o badaniach (bazy Omega-PSIR) generowane są dane:

— profile naukowców i jednostek;

- raporty dla władz uczelni;

— raporty dla ministerstwa;

— informacje dla Biznes/Media;

— silniki wyszukiwawcze (pełnotekstowe); sieci społecznościowe;

— systemy zewnętrzne OAI/PMH. 
Cele i zadania Bazy Wiedzy PW obejmują zarówno funkcje realizowane przez repozytorium, jak i system CRIS.

Tabela 2. Cele i zadania uczelnianej bazy wiedzy

\begin{tabular}{|c|c|c|}
\hline $\begin{array}{c}\text { Ewidencja i archiwizacja } \\
\text { (IR) }\end{array}$ & $\begin{array}{c}\text { Prezentacja i udostępnianie } \\
\text { (CRIS/IR) }\end{array}$ & $\begin{array}{l}\text { Analityka i sprawozdaw- } \\
\text { czość (CRIS) }\end{array}$ \\
\hline $\begin{array}{l}\text { pracowników i jednostek } \\
\text { dorobku naukowego i prac } \\
\text { dyplomowych } \\
\text { pełnych tekstów } \\
\text { dokumentów }\end{array}$ & $\begin{array}{l}\text { wymiana informacji z syste- } \\
\text { mami krajowymi } \\
\text { (np. INFONA) } \\
\text { ekspozycja dorobku nauko- } \\
\text { wego uczelni w świecie }\end{array}$ & $\begin{array}{l}\text { ocena pracowników } \\
\text { naukowych } \\
\text { raporty uczelniane } \\
\text { raporty ministerialne }\end{array}$ \\
\hline
\end{tabular}

Źródło: J. Koperwas, CRIS or repository? Is that a question. Czyli dlaczego warto wykorzystać system Omega-PSIR jako repozytorium instytucjonalne i CRIS $w$ jednym ${ }^{19}$.

System Omega-PSIR posiada cechy charakterystyczne zarówno dla systemów CRIS, jak i repozytoriów ${ }^{20}$ :

Tabela 3. Cechy repozytorium i CRIS w systemie Omega-PSIR

\begin{tabular}{|c|c|}
\hline Repozytorium & CRIS \\
\hline ujednolicone metadane bibliograficzne & model danych CRIS \\
\hline pełne teksty publikacji & raportowanie \\
\hline opcje automatycznej archiwizacji & łączność między jednostkami instytucjonalnymi \\
\hline protokół OAI-PMH & komunikacja z systemem POL-on \\
\hline
\end{tabular}

Źródło: J. Koperwas, op. cit.

\section{Rola Biblioteki Głównej w tworzeniu Bazy Wiedzy PW}

Biblioteka Główna zajmuje się koordynowaniem i organizacją aktualizacji danych w Bazie Wiedzy.

Do zadań Biblioteki Głównej należą:

— nadzór nad merytoryczną i funkcjonalną poprawnością metadanych;

— aktualizacja i dopisywanie danych wspólnych i formalnych;

- monitorowanie procesów archiwizacji utworów;

— szkolenia redaktorów i konsultacje;

19 Referat wygłoszony na III Ogólnopolskim Seminarium użytkownika oprogramowania uczelnianej bazy wiedzy Omega-PSIR, 20 czerwca 2016 r., Politechnika Warszawska.

${ }^{20}$ D. Zendulkova, CRIS and Repository application map, Bratislava, 11th November 2013, http://www.eurocris.org/Uploads/Web\%20pages/CRIS-IR_workplan/CRIS\%20and\%20Repository\%20application_2013Nov_web.pdf [dostęp: 8.07.2016]. 
— organizowanie seminariów i dni otwartych dotyczących Bazy Wiedzy, oprogramowania, otwartego dostępu;

— opracowywanie instrukcji i materiałów szkoleniowych oraz prowadzenie strony www;

— sporządzanie raportów z Bazy Wiedzy na potrzeby władz uczelni;

— przekazywanie metadanych do zewnętrznych systemów zarządzania nauką i szkolnictwem wyższym;

— koordynacja działań redaktorów wydziałowych, zarządzanie uprawnieniami;

- wnioskowanie do rektora o zmiany w organizacji i funkcjonowaniu bazy oraz o modernizację infrastruktury informatycznej, rozwój systemu;

- promowanie Bazy Wiedzy PW.

Jedno z istotnych zadań, w które zaangażowana jest Biblioteka Główna, to przekazywanie danych do zewnętrznych systemów zarządzania nauką. Biblioteka zobligowana jest Zarządzeniem Rektora $\mathrm{PW}^{21}$ do przekazywania informacji do systemu POL-on, a także eksportowania danych o publikacjach do PBN-MS.

Transfer danych o publikacjach odbywa się za pomocą eksportu tych informacji z Bazy Wiedzy PW ${ }^{22}$. Eksportem danych do PBN Modułu Sprawozdawczego (PBN-MS) zajmuje się administrator aplikacyjny nadający określone uprawnienia. Do PBN-MS przekazywane są zestawienia publikacji takich, jak książki redagowane, książki autorskie, rozdziały, artykuły. Eksport danych wykonywany jest dla podstawowych jednostek instytucji naukowej, w przypadku Politechniki Warszawskiej — wydziałów.

Zadaniami związanymi z Bazą Wiedzy PW zajmuje się w Bibliotece Głównej powołany specjalnie do tego celu Oddział ds. Bazy Wiedzy. Zakres prac Oddziału rozszerza się wraz z postępującym rozwojem Bazy Wiedzy. W związku ze współpracą z biznesem oraz takimi instytucjami, jak Polski Instytut Technologii czy Metropolitalne Centra Badawcze, przewidywane jest poszerzanie zawartości Bazy Wiedzy PW o inne rodzaje danych. Biblioteka musi być wcześniej przygotowana do wykonywania nowych zadań, jak administrowanie innymi zasobami informacji, typu dane surowe czy zasoby Big Data. Zmiany muszą dotyczyć nie tylko większych kompetencji i przygotowania pracowników Oddziału ds. Bazy Wiedzy czy innej grupy pracowników, lecz także znaczących działań w sferze organizacji i zarządzania biblioteką.

${ }^{21}$ Zarządzenie Rektora PW nr 49/2015 z dnia 30/11/2015 w sprawie wyznaczenia osób i jednostek odpowiedzialnych za gromadzenie, wprowadzanie, weryfikację, aktualizację i przekazywanie danych, https://www.bip.pw.edu.pl/Wewnetrzne-akty-prawne/Dokumenty-Rektora-PW/Zarzadzenia-Rektora/2015/Zarzadzenie-Rektora-nr-49-2015-z-dnia-30-11-2015 [dostęp: 9.07.2016].

22 M. Lewandowska-Tranda, M. Miller-Jankowska, Przekazywanie danych do Systemu Informacji o Nauce poprzez uczelnianq bazę wiedzy. Z doświadczeń Politechniki Warszawskiej, „Biuletyn EBIB” 2016, nr 165, http://open.ebib.pl/ojs/index.php/ebib/article/download/435/593 [dostęp: 8.07.2016]. 


\section{Podsumowanie}

System Omega-PSIR rozwijany w Politechnice Warszawskiej, zaimplementowany w ponad 10 instytucjach naukowych, umożliwia wykorzystanie uczelnianej Bazy Wiedzy zarówno jako repozytorium instytucjonalnego, jak i systemu CRIS. Rozwiązanie takie jest korzystne ze względu m.in. na niższe koszty utrzymania jednej instalacji. Funkcjonalności, w które jest wyposażona baza Omega-PSIR ${ }^{23}$, ułatwiają zarządzanie potencjałem badawczym i pomagają w realizacji strategii uczelni. Model konfiguracji odpowiedni dla określonej instytucji naukowej: repozytorium instytucjonalne i system CRIS, rozbudowane repozytorium czy system CRIS z rozszerzonymi funkcjami zależy jednak od różnych czynników. Na wybór typu instalacji wpływają: wielkość instytucji naukowej, wymogi raportowania, oceny naukowej, rodzaj gromadzonych danych, cele wykorzystywania informacji badawczych.

W związku z rosnącymi wymogami sprawozdawczości i parametryzacji jednostek naukowych uczelnie potrzebują efektywnych i gwarantujących rozwój rozwiązań typu instytucjonalna baza wiedzy, rozwijająca się zgodnie ze światowymi trendami naukowymi. W obsłudze nie tylko repozytoriów uczelnianych, lecz także baz CRIS czy instalacji typu Omega-PSIR mogą pomóc bibliotekarze. Jest to szansa dla bibliotek akademickich na pokazanie swego potencjału w nowego rodzaju działalności potwierdzającej przydatność dla uczelni i wzmacniającej jej pozycję. Współdziałanie z jednostkami uczelni wspomaga upowszechnianie i prezentowanie jej dorobku badawczego. Udział Biblioteki Głównej w procesie tworzenia Bazy Wiedzy PW, wyjście poza tradycyjne funkcje biblioteczne, ścisła współpraca z jednostkami naukowymi i władzami uczelni nie tylko pozwoliły na uzyskanie nowych doświadczeń i poszerzenie kompetencji, ale ukazały potencjalny przyszły kierunek rozwoju biblioteki uczelnianej.

\section{Bibliografia}

De Castro P., 7 things you should know about..., Institutional Repositories, CRIS Systems, and their Interoperability, https://www.coar-repositories.org/activities/repository-observatory/thirdedition-ir-and-cris/7-things-you-should-know-about-institutional-repositories-cris-systemsand-their-interoperability/ [dostęp: 8.07.2016].

Koperwas J., CRIS or Repository - is that a question. Czyli dlaczego warto wykorzystać system Omega-PSIR jako repozytorium instytucjonalne i CRIS w jednym. Referat wygłoszony na III Ogólnopolskim Seminarium użytkownika oprogramowania uczelnianej bazy wiedzy Omega-PSIR, 20 czerwca 2016 r., Politechnika Warszawska.

Kubrak W., From an institutional repository to the Base of Knowledge - case study, 8th Conference on Grey Literature and Repositories: proceedings 2015, https://repo.pw.edu.pl/docstore/ download.seam?fileId=WUT8af724cd51954f45b71d9b5262c09653 [dostęp: 8.07.2016].

${ }^{23}$ H. Rybiński et. al., op. cit. 
Lewandowska-Tranda M., Miller-Jankowska M., Przekazywanie danych do Systemu Informacji o Nauce poprzez uczelniana baze wiedzy. Z doświadczeń Politechniki Warszawskiej, „Biuletyn EBIB" 2016, nr 165, http://open.ebib.pl/ojs/index.php/ebib/article/download/435/593 [dostęp: 8.07.2016].

Lewandowska-Tranda M., Struk W., Omega PSIR a krajowy System Informacji o Nauce. Z doświadczeń Politechniki Warszawskiej, http://www.bg.pw.edu.pl/dane/publikacje/20_10_2015_ Sem_Omega_PSIR_WS_v2.pdf [dostęp: 11.07.2016].

Nixon W.J., Enrich: Improving integration between an Institutional Repository and a CRIS at the University of Glasgow, http://www.eurocris.org/Uploads/Web\%20pages/cris2010_papers/ Papers/cris2010_Nixon.pdf [dostęp: 12.07.2016].

Open AIRE Guidelines for CRIS Managers based on CERIF-XML, https://guidelines.openaire.eu/ wiki/OpenAIRE_Guidelines:_For_CRIS [dostęp: 8.07.2016].

PREMIS Preservation Metadata Maintenance Activity. Official Web Site, https://www.loc.gov/ standards/premis/ [dostęp: 8.07.2016].

Ribeiro L., De Castro P., Mennielli M., EUNIS - euroCris joint Survey on CRIS and IR. Final Report, http://www.eunis.org/wp-content/uploads/2016/03/cris-report-ED.pdf [dostęp: 8.07.2016].

Rozporządzenie Ministerstwa Nauki i Szkolnictwa Wyższego z dnia 27 października 2015 r. w sprawie kryteriów i trybu przyznawania kategorii naukowej jednostkom naukowym, Dz.U. 2015, poz. 2015, http://isap.sejm.gov.pl/DetailsServlet?id=WDU20150002015 [dostęp: 8.07.2016].

Rozporządzenie Ministerstwa Nauki i Szkolnictwa Wyższego z dnia 29 czerwca 2015 r. w sprawie Systemu Informacji o Nauce, Dz.U. 2015, poz. 944, http://isap.sejm.gov.pl/DetailsServlet?i$\mathrm{d}=$ WDU20150000944 [dostęp: 8.07.2016].

Rybiński H. et al., OMEGA-PSIR: From the Repository to the Research Knowledge Base of Warsaw University of Technology, „Foundations of Management” 2013 (5), nr 1.

Skonieczny Ł., OMEGA-PSIR. Nowe funkcje. Październik 2015-Czerwiec 2016, http://repo.bg.pw. edu.pl/images/dokumenty/omega_news_skonieczny-1.pdf [dostęp: 13.07.2016].

Stępniak J., Baza Wiedzy PW, http://repo.bg.pw.edu.pl/images/dokumenty/BW_PW_2016_klub_ uzytkownikow_J_Stepniak.pdf [dostęp: 8.07.2016].

Stępniak J., Krajowy system informacji o nauce — szansq dla bibliotek szkół wyższych, VII Konferencja Biblioteki Politechniki Łódzkiej „Rozmowy o bibliotekach”, 22-24 czerwca 2016 r. Łódź-Rogów, http://7kbpl.systemcoffee.pl/userfiles/file/prezentacje/11-Stepniak.pdf [dostęp: 7.07.2016].

Uchwała nr 26/XLVIII/2012 Senatu Politechniki Warszawskiej z dnia 21 listopada 2012 r. w sprawie utworzenia centralnego systemu ewidencji i archiwizacji dorobku piśmienniczego, wydawniczego i dydaktycznego, pracowników, doktorantów, studentów i jednostek Uczelni oraz repozytorium Politechniki Warszawskiej, https://www.bip.pw.edu.pl/content/download/23324/218057/file/26.pdf [dostęp: 7.07.2016].

University of Glasgow: Enlighten IR and Research System, https://www.coar-repositories.org/files/ Profile-UofG.pdf [dostęp: 8.07.2016].

Zarządzenie nr 03/2014 Rektora Politechniki Warszawskiej z dnia 29 stycznia 2014 r. w sprawie centralnego systemu ewidencji i archiwizacji dorobku piśmienniczego, wydawniczego i dydaktycznego, pracowników, doktorantów, studentów i jednostek Uczelni oraz Repozytorium Politechniki Warszawskiej, https://bip.pw.edu.pl/content/download/25491/241495/file/z\%20 3_2014.pdf [dostęp: 7.07.2016].

Zarządzenie Rektora nr 30/2015 z dnia 3 lipca 2015 r. zmieniające zarządzenie nr 27/2015 Rektora Politechniki Warszawskiej w sprawie wprowadzenia do systemu USOS-APD i Bazy Wiedzy Politechniki Warszawskiej pisemnych prac dyplomowych: licencjackich, inżynierskich i magisterskich, udostępniania ich oraz przekazywania do Zintegrowanego Systemu Informacji o Nauce i Szkolnictwie Wyższym POL-on, https://www.bip.pw.edu.pl/Wewnetrz- 
ne-akty-prawne/Dokumenty-Rektora-PW/Zarzadzenia-Rektora/2015/Zarzadzenie-Rektora-nr-30-2015-z-dnia-3-07-2015 [dostęp: 9.07.2016].

Zarządzenie Rektora PW nr 49/2015 z dnia 30 listopada 2015 r. w sprawie wyznaczenia osób i jednostek odpowiedzialnych za gromadzenie, wprowadzanie, weryfikację, aktualizację i przekazywanie danych, https://www.bip.pw.edu.pl/Wewnetrzne-akty-prawne/Dokumenty-Rektora-PW/Zarzadzenia-Rektora/2015/Zarzadzenie-Rektora-nr-49-2015-z-dnia-30-11-2015 [dostęp: 9.07.2016].

Zendulkova D., CRIS and Repository application map, Bratislava, 11th November 2013, http:// www.eurocris.org/Uploads/Web\%20pages/CRIS-IR_workplan/CRIS\%20and\%20Repository\%20application_2013Nov_web.pdf [dostęp: 8.07.2016].

\title{
The university base of knowledge as a CRIS type system. The experience of the Main Library of WUT
}

\begin{abstract}
Summary
The paper presents the university base of knowledge as a CRIS type system and at the same time an institutional repository. Systems CRIS (Current Research Information System) currently being developed by the scientific community gather comprehensive Information about research conducted at individual institutions. The WUT Base of Knowledge using proprietary software OMEGAPSIR is an example connecting system CRIS and a university repository, collecting and preserving intellectual output of WUT. Base of Knowledge is a source of information on the directions of research conducted at the university. The base has many uses: data collection, content archiving, analytical tools and reporting, extensive system parameterization. Academic libraries, participating in the creation of university's databases, perform an important task for the university, other than the traditional functions of librarians.
\end{abstract}

KEYWORDS: university knowledge base, institutional repositories, system CRIS, intellectual output preserving, academic libraries, university achievements, research outputs. 